\title{
Understanding Attitudes to Paying for Care amongst Equity Release Consumers: citizenship, solidarity and the 'hardworking homeowner'
}

\begin{abstract}
The importance of developing a system that is perceived to be 'fair' is a central element in debates about long-term care funding in the UK. It is therefore surprising that while previous research has established that older people tend to resent the idea of using housing equity, and other personal assets, it has often revealed little about the factors underpinning these attitudes or reflected on how they sit within a wider frame of social and political norms. Drawing on 60 semi-structured in-depth interviews with older home owners who have released equity from their homes, this paper explores why people feel that it is fair, or unfair, to require owners to use their housing equity to fund long-term care needs, once factors like reluctance to trade on the home, and mistrust of equity release products, have been excluded. While a small majority of our participants considered it unfair, a substantial minority thought it fair that they were required to use their accumulated housing equity to meet care needs. This distribution of attitudes enabled us to explore the reasons why participants held each view, and so reflect on the impact of pro-social and pro-individual norms in shaping attitudes towards intra-generational fairness and ideas about 'responsible citizenship'. Our analysis posits that the factors that shape attitudes toward using housing assets to pay for care, and their relationship to the wider rhetorical framework of asset accumulation, management and de-cumulation, have been misunderstood by policy makers. We discuss the implications of our findings for policies that seek to promote the development of a housing-asset based care funding system capable of attracting widespread support.
\end{abstract}




\section{Introduction}

The challenges of developing sustainable strategies to meet the projected needs of ageing populations have prompted widespread policy debates (The World Bank, 2004; Nyce \& Schieber, 2005). The challenges of resourcing long-term care needs in a context of increasing demand (Glendinning et al, 2004; Mossialos et al, 2002) have been underscored by pressures on informal or unpaid care, historically an essential part of many long-term care systems (Kraus et al, 2011). In England, the number of older people in need of care is predicted to outstrip the number of family members able to provide it for the first time in 2017, with this shortfall in our collective capacity to care for older generations rising significantly in subsequent years (Pickard, 2013). Meanwhile, real-term spending on social care in England has fallen by $£ 770$ million since 2010, and waiting times for care home places, home care, and adaptations have increased (Age UK, 2014). The UK's House of Lords Select Committee on Public Service and Demographic Change has recognised that 'social care and its funding are already in crisis, and this will become worse as demand markedly increases' (House of Lords, 2013).

The role of accumulated housing wealth has been an important - and controversial - theme within care funding debates, against a backdrop of asset-based welfare policies which encourage ('responsible') citizens to accumulate, manage, and strategically decumulate a pot of (housing) assets to underwrite their consumption and welfare needs in later life (Doling and Ronald, 2010). The proposition that housing asset-based welfare may help reduce the fiscal funding gap is underpinned by the concentration of housing wealth in the older generation. In 2009 it was estimated that British owner-occupiers aged 55 and over owned $£ 1,360$ billion worth of net housing wealth (in contrast to just $£ 330$ billion for those aged under 44) (Willetts, 2010), and latest figures from the Wealth and Assets Survey (ONS, 2015) reinforce this generational pattern. While housing wealth typically increases as people age and move into mortgage free ownership, timing is also significant here, and the 'windfall' nature of much baby-boomer housing wealth is framed by a political discourse that has focused on inter-generational justice. Although considerable within generation inequalities exist (Searle and McCollum, 2014), the older generation, broadly speaking, have benefited from substantial house price gains and inflation-driven reductions in the relative size of their mortgages (Willetts, 2010), while the younger generation - one of the most indebted cohorts in modern history (Boreham and Lloyd, 2007) - are increasingly excluded from homeownership and, in turn, from future participation in the asset-based welfare society (McKee, 2012).

These inter-generational differences have also been prominent in care funding debates, underpinning the importance of reducing reliance on the working generation through general taxation and the key role of housing equity in contributing to a fairer settlement. In Shaping the Future of Care Together, the Government signalled that:

The generation currently in their 50s and 60s, or older, has benefited in particular from massive increases in property prices, as well as free higher education and other advantages... we know that there is very wide inequality among older people. But the group of people over 60 remain the wealthiest generation that this country has ever seen' (HM Government, 2009: 90).

This perspective was buttressed by the suggestion (among younger people) that since older people's housing wealth 'was not something they had earned' policies that enabled them to 
'have an automatic right to keep it, at the expense of younger generations [through the tax burden]' were unfair (HM Government, 2009: 91). This narrative stands in stark contrast to political rhetoric around hard-working homeowners: for example, when Health Secretary Jeremy Hunt announced the latest reforms to social care funding in 2013, he said:

'...the issue of social care has been ducked by successive governments, leading to an unfair system that has seen people selling their homes and losing nearly everything they've worked for to pay for their care. With us, that unfairness is ending. These historic reforms will give everyone the protection they want in their old age and save the family home. And they prove once again that despite these tough economic times, this government is determined to get behind everyone who has worked hard and done the right thing...' (Department of Health, 2013)

. Lucky windfall or hard-earned asset, asset-based welfare policies depend not only on enabling asset accumulation and decumulation, but on effectively incentivising older people to deploy accumulated (housing) assets in ways that are aligned with social policy goals (Taylor-Gooby, 2008), as 'active citizens' in the new world of welfare.

The success of these complex strategies is likely to be determined, in no small measure, by the extent to which the responsibilities placed on asset-holders to self-provide (while the state continues to provide a safety-net for those who do not hold sufficient assets) are perceived by the asset-holders as 'fair'. Yet, previous research has indicated that, broadly speaking, the current requirement on owners to spend down their housing assets before qualifying for state support with care costs is viewed as 'unfair' (Ipsos Mori, 2011). To this end, the Care Act 2014 - which set out to consolidate and modernise the legal framework governing adult social care in England, including the reform of care funding arrangements - represents the Government's latest attempt to broker a 'fair and sustainable' solution to the pressing problem of care costs. In capping the individual care recipient's contribution to the costs of care from their own accumulated assets at $£ 72,000$, the Act aimed to strike a 'fair' balance between state and individual responsibility for care costs, by protecting people from catastrophic costs, to provide a clearer idea of what they may need to provide for, and to make it easier to plan ahead. Reflecting on the operationalisation of this new regime, the Government has also underlined the important role the financial services industry will play in developing products that enable people to leverage assets, particularly housing equity, to fund the capped contribution of up to $£ 72,000$ without having to sell their homes (Association of British Insurers, 2014; Commission on Funding of Care and Support, 2011).

One way of leveraging housing equity is through 'equity release', a distinct category of home finance product offered exclusively to older consumers which enables housing equity withdrawal without an immediate repayment obligation, and while continuing to live at home. Notwithstanding a recent increase in sales, the UK equity release market remains small at less than 2 per cent of the mainstream mortgage market (Overton and Fox O'Mahony, 2015). Nevertheless, the House of Lords Select Committee on Public Service and Demographic Change have emphasised the strategic importance of 'an effective equity release market to unlock the housing assets held by older people' (House of Lords, 2013, p. 41), to 'enable more people to use their assets to help pay for the cost of their social care, to adapt their homes, and to support their incomes' (p. 138). One barrier to this strategy has been that while some people like the idea of equity release in theory, products are often perceived as inherently risky, with common concerns relating to security and value for money (Rowlingson, 2006 (UK); Ong et al., 2013 (Australia); CFPB, 2012 (USA); Touissant \& 
Elsinga, 2009 (Europe). A qualitative study commissioned by the Dilnot inquiry (Hewitson et al, 2011) indicated that one of the least favoured options to meet care costs was release of housing assets. Similarly, in their study on financial planning for social care in later life, Price et al. (2014) found that none of the participants were willing to contemplate equity release.

In contrast to these general population studies, this article draws on a qualitative study of older owners who have already released equity from their homes through private sector transactions, to explore the factors that underpin attitudes once factors like reluctance to trade on the home, and mistrust of private providers, have been excluded. The older owners' perspective is important in this context since - having adopted 'active citizen' accumulation behaviours - they are the population whose decumulation decision-making will have a significant bearing on the feasibility of housing-asset-based welfare strategies. In sharpening our focus on equity release consumers, we recognised that they may be more relaxed about spending housing wealth, given that they had already done so to meet a range of income needs and preferences. Although this was not always through choice, and sometimes as a last resort, participants were generally satisfied with the outcome, thus (Fox O'Mahony \& Overton, 2014a)their attitudes were less likely to be coloured by the general population's mistrust of private sector equity release schemes (cf, Croucher \& Rhodes, 2006: 38). On the other hand - having already depleted their stores of housing wealth - participants may have been reluctant to use remaining housing wealth to pay for care, particularly if they hoped to leave a bequest. Finally, we noted that exploring the attitudes of home owners who - through choice or necessity - have already begun to decumulate may also open up avenues for further research into the attitudes of the growing population of owners who practice decumulation across the life course (Smith \& Searle, 2008).

We begin by reviewing earlier research into attitudes to care funding, and outlining the conceptual framework through which we analyse our findings, before setting out our research methodology and findings. The discussion seeks to offer a deeper understanding of older people's attitudes to paying for care, as these relate to housing equity accumulation and decumulation within the policy framework of asset-based welfare. We reflect on the impact of the 'ownership society' on ideas about 'fairness', citizenship, and individual and collective responsibility as well as changing norms of intra- and inter-generational justice. Finally, we consider the implications of our findings for strategies that seek to support a transition from 'ownership society' to an 'asset-based welfare society' in which more owners are motivated to manage their housing equity with a view to planning for their potential future care needs.

\section{The role of 'fairness' in attitudes to care funding}

The perception that it is 'unfair' to require older people to draw upon their own resources has often been linked to suggestions that housing assets represent a distinct form of accumulated wealth. According to a recent report:

'An ageing population has placed growing strains on public funding for care, while those aged 65 or over now hold an estimated $£ 750$ billion of unmortgaged housing equity. Yet the cultural attachment to housing in the UK and the desire of people to pass something on to their children has made linking these two things politically toxic.' (Mayhew and O'Leary, 2014: 17).

This resonates with a raft of research in the late 1990s explaining popular resistance to using housing wealth to pay for care through three key ideas: (1) that elderly people should be allowed to preserve accumulated assets for inheritance (Jarvis et al, 1998); (2) that taxes 
should pay for residential care (Parker and Clarke, 1997); and (3) that people resented the prospect of being 'forced' to sell their home because they believed themselves, as propertyowning individuals, entitled to make their own decisions about whether, when, how and why they use their assets (Finch and Mason, 2000). Croucher and Rhodes (2006) reported that only a very small minority of respondents believed that older owners should be required to self-provide, with respondents - both owners and non-owners - particularly opposed to compelling the sale of a home to pay for care (although the gradual release of some equity, if this could be achieved through a government guaranteed scheme rather than through the private sector, provoked less strong resistance). Hewitson et al's (2011) study reported that only seven per cent viewed housing equity as a preferred method of paying for care, with most describing it as an option to be avoided, and some as a last resort.

While earlier research has highlighted a range of arguments against self-provision, much of the existing literature is primarily focused on what people's attitudes are (Erens and Turner, 1997; Parker and Clarke, 1997; Deeming and Keen, 2003; Opinion Leader, 2009). Croucher and Rhodes (2006) offered some insights to the general population's attitudes with their finding, drawn from focus groups with 59 participants aged 26-90, that policies that force the use of personal assets are perceived to penalise thrift. They reported that although participants felt that the state should support those without sufficient means to pay for themselves, this was undercut by the feeling that those who had 'squandered' money 'got everything free', while others with often meagre assets were effectively penalised by the state after a lifetime of hard work (35). The construction of recipients of public funding as 'undeserving' is consistent with Hills'(2014) portrait of a nation divided according to those who have paid into the welfare state, and those who benefit from it. It also echoed the Government's own public engagement work, which noted that: 'although people agreed that those who could not afford to pay for themselves had the greatest need for state support, they also felt it was unfair that people who had worked hard and made sensible decisions to save were less eligible for state support' (HM Government, 2009: 14).

Our analysis set out to explore how older owners (who have already used equity release products) conceive of 'fairness' when it comes to using housing equity to pay for care, what underpinning values and assumptions drive their views, and how 'pro-social' ideas of assetbased welfare (with contributions according to ability to pay and provision according to needs) intersect with the norms of the 'pro-privatisation' 'ownership/accumulation society'.

\section{Methodology}

This article draws on semi-structured, in-depth, interviews with equity release consumers, as part of a wider study into housing wealth and wealth inequalities within and across generations ${ }^{1}$. Our qualitative interviews explored consumers' needs, circumstances and decision-making processes, and their attitudes to housing wealth and the use of housing equity in paying for care. The recruitment of participants was facilitated by a previous equity release study (Overton, 2010). We wrote to all those who had agreed to take part in future equity release research (251 people), asking if they would like to be part of this project. Of this sample, 70 opted to take part in the 2013 study, of which 60 expressed views about care funding. The sample was sufficiently diverse (in terms of key characteristics) to enable us to explore potential differences in attitudes between, for example, more and less financially secure participants and those with and without children.

\footnotetext{
${ }^{1}$ Mind the (Housing) Wealth Gap: Intergenerational Justice and Family Welfare, funded by the Leverhulme Trust, RP2001-IJ-024.
} 
Using participants' self-reported financial situation before taking out equity release (captured in the 2009 survey), the sample was divided into higher and lower financial wellbeing categories. Those placed in the lower category had stated that before taking out their equity release plan they were 'finding it very difficult to get by', 'finding it quite difficult' or 'just about getting by'; while those deemed to have higher levels of financial wellbeing had reported that they were either 'doing alright' or 'living comfortably' (Table 1).

Table 1 Sample sub groups

\begin{tabular}{l|l}
\hline & Number \\
\hline $\begin{array}{l}\text { Self-reported financial } \\
\text { situation }\end{array}$ & \\
Lower & \\
Higher & 34 \\
Household type & 36 \\
Couples & \\
Single female & 30 \\
Single male & 22 \\
& 18 \\
Age & \\
$66-70$ & \\
$71-75$ & 5 \\
$76-80$ & 16 \\
$81-85$ & 20 \\
$85+$ & 24 \\
Children & 5 \\
Yes & \\
No & \\
House value on entering & \\
into equity release* & \\
Under $£ 100,000$ & \\
$£ 100,000-£ 149,999$ & 67 \\
$£ 150,000-£ 199,999$ & 10 \\
$£ 200,000-£ 299,999$ & 21 \\
$£ 300,000$ or more & 21 \\
\hline
\end{tabular}

* Participants were asked to state how much their houses were worth at the time of transacting. It is not known how much of this value was unmortgaged, but consumers are required to pay off any outstanding mortgage with some or all of the money received as part of the plan.

The interviewees were geographically dispersed, with 68 from across England and Wales, and two in Scotland, with the majority of interviews conducted by telephone. On a small number of occasions this method was not suitable due to hearing impairments, so face-to-face interviews were carried out instead. All interviews were recorded, with the prior permission of participants, and transcribed. Participants have been given pseudonyms and the quotations used do not contain identifying information. While we note that Scotland currently takes a 
different approach to means-testing for social care compared to England and Wales, our questions were not focused on the mechanics of the different systems, but asked participants to reflect in a more abstract sense on the 'in principle' issue of using housing equity to pay for care.

We applied the framework analysis method (Spencer et al, 2003) to interrogate patterns within the data along key themes, including 'attitudes to paying for care'. Within this theme, we constructed an overarching thematic chart, enabling us to unpack the broad theme before developing smaller charts containing refined sub-themes. Each row in the matrix represents an interviewee while each column contains data from their transcript relating to the particular theme/sub-theme. Organising the data in this way enabled us to explore the range of responses and the differences and similarities across cases, not only at the individual case level but also within and across categories.

\section{Fairness for the asset-holders: personal responsibility, 'hard-working homeowners' and intra-generational (un)fairness}

Participants generally accepted that they would be required to make some contribution towards the costs of their care in later life although - in contrast to earlier findings suggesting that older people were particularly likely to resent self-provision, (Hewitson et al, 2011) - just over half felt that the current system was 'unfair'. When we explored the thinking behind those views, we found - in contrast to some earlier findings (Finch \& Mason, 2000), popular media tropes (Daily Mail, 2014), and political rhetoric (DoH, 2013) - little evidence that reluctance to pay for care using housing wealth was rooted in strong support for inheritance, or in cultural attachments to the owned home. Only three participants explained their views with reference to emotional attachment to home, or because self-provision would deprive them of an inheritance opportunity. This may explain why there was no particular relationship between those who considered self-provision fair or unfair, and whether or not participants had children; although we noted that in some cases, participants with children had already used released equity to help their children, which may have influenced their remaining inheritance motive. It was also interesting to note that relative economic status (measured according to income and asset levels) did not appear to explain why some participants were satisfied that contributing to care costs from their personal asset base was 'fair', and others were not. Similarly, the purpose for which participants had used equity release did not offer any explanation for variation in attitudes.

Where our findings identified an underlying explanation for differences in attitude it was linked to participants' perceptions of why some people within their own generation managed to save, while others had not. For those who thought it was unfair that they were expected to contribute to their own costs from stores of housing equity, this was underpinned by the belief that people who reached later life with higher levels of income and assets had done so through thrift and individual responsibility, while those with lower levels or no housing wealth or savings had personally failed to accumulate, and so were 'undeserving'. These participants often explained their attitudes with reference to their own experiences of having 'done the right thing' by paying taxes and mortgages. For example, Marion, one of our better off participants, who lived alone and used equity release to support a friend in financial difficulty and to make improvements to her house, said: 
I think it is a disgrace that you have paid all your taxes all your life... You've not demanded anything from the state because you've been fortunate enough to have been educated and you've managed to deal with it all yourself...you are then expected, because you've got the money, to pay for it and yet people who, and we all know them...have been in the same position and they've just squandered everything and then they get it paid. (Marion, age 73, no children, released $£ 50,000$ from house valued at $£ 200,000)$.

Roger also described his sense of the 'unfairness' ('I think it's a crime') of a policy whereby people without assets 'get it given to them' while 'people who have worked and done everything they should do and saved and done all the correct things, they get kicked... I think it's totally, totally wrong. (age 76, married, children, lower financial well-being, used ER to clear debts, released $£ 40,000$ from house valued at $£ 150,000$ ).

For these participants, 'fairness' was expressed in terms of their own sense of agency and good citizenship, as successful asset-accumulators. As Joseph said: 'I don't think it's fair, because if you've been diligent... you do tend to be penalised, to be honest...'(age 76, married, children, lower financial well-being, used ER to support son starting a business and make home improvements, released $£ 40,000$ from house valued at approx. $£ 200,000$ ). Nevertheless, it is interesting to note that, while Marion acknowledged her good luck - that she had been 'fortunate enough to have been educated and...managed to deal with it all myself' - when she contrasted her own experience with those who had less assets in later life, she assumed that others had enjoyed the same opportunities but behaved differently: 'the people who have been in the same position and they've just squandered everything and then they get it paid'. This is consistent with research indicating that while people recognise, and accept as 'fair', the targeting of state support at those in greatest 'need' (DWP, 2009), this is qualified by their perceptions - shaped through the public narrative - of the legitimacy of claims to public services, based on the 'deservingness' of the claimant; with perceptions of 'deservingness' based on the extent to which individuals are perceived to have had personal choice over their circumstances; and the amount of effort they put into changing their situation, assuming they were able to do so (DWP, 2009).

Participants in our study who regarded means-tested policies as 'unfair' tended to emphasise relative intra-generational disadvantage for responsible saver-citizens who have 'done the right thing'. Some participants contrasted owners who 'struggle to pay the mortgage' with tenants who 'squander', reflecting the caricatures that have framed popular conceptions of tenure, particularly since the 1980s: of owners as morally responsible and tenants as an irresponsible, dependent and 'undeserving' housing class (Gurney, 1999). Gerald began by suggesting that asset-holders should self-provide: 'I think there should be some contribution because they've accumulated that property over their lifespan and it isn't really the State's responsibility to look after them...'; although he struggled between accepting selfresponsibility, on the one hand, and concern that it encouraged 'free-loading', on the other:

The only objection I have is people who have just frittered it all away or whatever, or they live in a rented property and they're in the pub every night and they've no money anyway, I think they should be penalised somewhere, but I don't know how you'd do it, I don't know how you do it because whichever colour government they have to look after the people who can't manage themselves, don't they? (age 79, married, children, 
higher financial well-being, used ER to help son clear his university debt and get on the housing ladder, released $£ 79,500$ from house valued at $£ 240,000$ ).

David also explained his view that means-testing was unfair by contrasting:

... people who suffer to pay their mortgage, and they get their house, and they've got the value in it, and they find themselves having to pay for [care], whereas if you didn't struggle to pay the mortgage, and you just spent all the money down the pub seven nights of the week, and retire with nothing, you get exactly the same quality of care. You're paying for it and they're not. (age 76, married, children, higher financial well-being, used ER to help son in financial difficulty, released $£ 30,000$ from house valued at $£ 320,000$ )

This was interesting in light of David's description, in another part of the interview which explored participants' own experiences of accumulating equity, of the relative ease with which he had accumulated housing wealth, and the 'ridiculous' increase in property values which had delivered his equity gain. Across our findings, we did not identify any generalised pattern in attitudes according to whether participants regarded their accumulated housing equity as 'hard earned' or 'windfall'. Further research would be needed to explore whether, in this context, it is not only asset-owning, but the process of accumulating assets, that creates an 'asset effect' in the way people think and behave (Prabakhar, 2008).

Difficulties in reconciling value commitments to 'fair and equal access', on the one hand, and 'asset-holder attitudes' to self-provision on the other, also emerged amongst participants who viewed means-testing as unfair. For example, Joseph said:

I'm a great believer in the welfare state... but I don't think it's right that people who haven't got any housing equity should get supported and people who have should have it taken off them, because it does seem to be unfair in that respect.

There is a further paradox in Gerald's construction of those who have not saved: on the one hand, he suggests that they have chosen to behave irresponsibly when they could have done otherwise, implying personal fault that should be penalised; but, at the same time, he accepts that the government has to take care of 'the people who can't manage themselves'. Marion also made a distinction between those who can and cannot 'manage', articulated through a moral rhetoric of strong values: 'We were brought up to try and manage our own affairs...'. Those who had not followed the same norms of good behaviour - who had not accumulated housing assets - were seen to have benefited from their failings: 'it seems a little bit if you haven't looked after things, you tend to get more benefits or help...'

The contradiction between an asset-holder perspective rooted in the moral/behavioural highground of having 'done the right thing', on the one hand, and the myth of choice - and reality of unequal opportunity to accumulate wealth - on the other, implies that these participants' attitudes were influenced by the extent to which they assumed equal opportunity to 'do the right thing' by accumulating equity. This narrative of behaviour and choice sits uneasily with the reality that significant place-specific and socio-economic variations in the 'windfall' effect of price mean that housing investment in the UK generates unequal returns (Burrows, 2003; Dorling et al, 2007), with homeownership less profitable and more risky for those on lower incomes (Maxwell \& Sodha, 2006). This myth of a level-playing field for housing 
equity accumulation resonates with official narratives of equal opportunity to accumulate resources through homeownership: for example, the policy claim that strategies to expand the home ownership sector 'offered people opportunity and choice - to own their own home, to meet their aspirations and to build up assets' (ODPM and HM Treasury 2005: 1).

Perceptions of non-asset holders within their own generation as 'undeserving' were compounded for some participants by the view that their own good behaviours of assetaccumulation made them more deserving of state support in relation to care costs than those who had not successfully accumulated housing equity. These owners resented the idea of using their housing equity to pay for care in light of their track-record of working hard and behaving responsibly: '[We] worked all our lives, and paid in our pension and our tax and national insurance and everything. I think at that rate we should be owed something in our final years.' (Ellen, age 70, married, no children, lower financial well-being, used ER to supplement low pension income and enhance lifestyle, released $£ 77,500$ from house valued at $£ 250,000)$. Irene also suggested that it was unfair that people who had not accumulated an asset pot would receive the same level of care as those who self-provide:

the point that I've done all that, got my own house, didn't go to anybody for anything, and the fact that somebody else has been sitting on their backside all their lives getting, scooping it off of the nation, if you like, and they won't have anything to sell, and they'll get the same treatment as me. That bugs me a bit. It may sound like I'm a bit selfish, but it bugs me. (age 86, living alone, children, higher financial well-being, used ER to enhance her lifestyle, could not see point of 'sitting' on value of house and not using it, released $£ 30,000$, house value unknown).

These tensions go to the heart of the lack of consensus about whether ability to pay should determine the nature and extent of the state's responsibility to fund later life care costs. Amongst our participants, those whose attitudes were based on 'fairness for the asset-holders' tended to overlook inequalities in the opportunity to accumulate assets for later life. This aligns with an 'ownership society' rhetoric that implies equality of opportunity, given the right behaviours, for 'hard working homeowners' to accumulate housing equity. Yet, our findings suggest that this very rhetoric could promote a mindset that leads to perverse behaviours, if those who have resources respond by deliberately depleting their asset base, in a race to the bottom to achieve 'fairness' relative to those who do not have to pay. While we did not find significant evidence of this in our sample, one participant admitted to using equity release to decumulate his asset base before he needed care, and to avoid inheritance tax. Reflecting on his parents' experience of paying for care, Paul said:

My father is 101. My mother is 100. My father worked all his life. He never went to the pub every day, or even every week, or even every month...He never went down to the bookmakers. He invested it all in his house and things like that. And then, when he was 95, and they both had to go in a home, he's had to spend all that money, so he's now got nothing left...How do you think he feels? He must feel absolutely terrible, that everything he worked for has all gone. Whereas if, during his working life, he'd gone to the bookmakers every day, he'd gone to the pub every day for his beer, and finished up with no money and no pension at the end of it, when he had to go into a home, the state would have paid.

Talking about how this had shaped his own behaviours, Paul explained that his reason for releasing equity from his 5 bedroom house, valued around $£ 800,000$, was: to reduce the size 
of our estate, and spend the money, before the taxman gets at it (age 74, married, children, higher financial well-being, released $£ 60,000$ ). While our findings on this point are not sufficiently robust to draw conclusions from, we speculate that if the relative, withingeneration, conception of fairness for the asset-holder' discussed in this section - which assumes equal opportunity to accumulate housing equity - were to have the effect of inclining some older owners to believe that 'fairness' for hard-working homeowners justifies spending down assets to achieve a level-playing field with those who have 'squandered', this would signal a risk that 'ownership society' rhetoric may run counter to the goals of assetbased welfare.

\section{Fairness for the non-asset holders: self-provision, luck and inter- generational fairness}

A substantial minority of the participants in our study believed that it was fair for older owners to use their housing equity to pay for their own care needs. We have noted that this appears to run counter to Hewitson et al's (2011) findings that older people and people from lower income groups were more likely to adopt a 'them' ('people who hadn't worked hard and paid into the system') and 'us' (those who had) mentality([3.2.1]); while younger people were more likely to recognise an individual's 'civic duty' to share, in partnership with the state, the costs of unforeseen needs (para 3.2.2). Our study was conducted in 2013, following a prolonged period of strong political rhetoric relating to the state's inability to meet the rising costs of pensions and care for an ageing population, and it may be that some of our participants had internalised these messages. For example, Ted framed his support for the use of housing equity in pragmatic terms, noting that:

The cost of care has got to be met somehow. If one's property isn't used then where does the money come from? I think the whole process...isn't right. However, having said that, where's the money coming from? (age 80, living with partner, children, higher financial well-being, used ER to discharge debt and for home improvements, released $£ 30,000$ from house valued at $£ 200,000$ )

Similarly, Gladys felt that while giving up her home would not be easy, it was one of those extremely regrettable, but understandable necessities... I don't see an alternative. Where else would the cost come from? (age 81, widowed, children, lower financial well-being, used ER to pay for everyday living expenses, released $£ 62,000$ from house valued at $£ 180,000$ )

Many of those who felt that it was fair to expect home owners to draw upon their own resources mentioned 'personal responsibility'. For example, Eleanor, a well-off owner who withdrew (but did not ultimately spend) equity when her husband was ill, said:

I think if you're lucky enough to own a house and you owe somebody some money for looking after you, you can jolly well sell the house and pay them. (age 90, widowed, no children, higher financial well-being,released $£ 100,000$ from house valued at $£ 600,000)$.

Others mentioned that their attitudes were tempered by the generational and individual advantages they had experienced:

As a general rule I think it can stink a bit, to be rather vulgar. But I understand we've been very lucky with our NHS since it was first introduced and I'm luckier than many, many people. So I guess it's fair enough... I don't want to be a sponger. And I just 
feel for those that are in a worse off condition than I am. (Nancy, age 78, living alone, no children, higher financial well-being, used ER for home improvements and to enhance lifestyle, ).

Nancy's feeling that she had been 'lucky', and her sensitivity towards those who were less well off, contrasts with the responses discussed in the previous section, which tended to view housing equity as 'hard earned', and non-asset holders as 'undeserving'. A common feature for those participants who supported self-provision was the absence of any sense of intragenerational unfairness or an 'undeserving poor'. Those who supported self-provision typically valued pro-social self-provision over 'individual rights'. For example, Peggy - who did not consider housing equity 'hard earned' (she said house prices rose 'ridiculously' in the 1980s) felt that she should be responsible for her own care as long as possible:

Why should somebody else keep me...I think a lot of people really are intent on leaving their family the inheritance...I think if somebody's got the money they must look after themselves. (aged 81, divorced, foster children, lower financial-wellbeing, used ER for new kitchen, released $£ 10,000$ from house valued at $£ 80,000$ ).

Betty - who had struggled to pay her mortgage during the acquisition phase - also echoed this view: if they've got a very expensive property, why leave it to the children when they could be paying for themselves? (age 86, living alone, no children, lower financial wellbeing, used ER for everyday living expenses, sold 90 per cent share of house valued at $£ 40,000$ in return for monthly income of $£ 190^{2}$ ).

The relative lack of emphasis on inheritance motives in our study may reflect the nature of the sample, or possibly a broader decline in support for inheritance (Rowlingson and McKay 2005); although this shift has typically been more strongly associated with younger cohorts. Alternatively, our findings may reflect a 'cohort effect'. Henry, who supported self-provision explained:

I'm of a much older generation and when I was young the thought of inheriting property was regarded as almost criminal...I never inherited anything and it didn't do me much harm. (age 81, married, children, higher financial well-being, used ER as no longer wished to have money invested in property. Sold house for 1.2 million and gifted a large proportion of the proceeds to children. Could not buy new property of the size he and his wife wished for using remaining $£ 600,000$, so used a certain type of equity release plan to purchase more expensive property)

The majority of participants in our study entered homeownership in the late 1960s/1970s, before the official rhetoric of 'housing as inheritance' took hold within the UK's 'home ownership' narrative (Hamnett et al, 1991). In another section of the interview, when we asked our participants about the main reason they became a home owner, only one (who become a homeowner later in life, after leaving the army) said that they had bought the property to have something to bequeath; rather, participants commonly explained their decision with reference to security, having a place to call their own, or because it was simply 'the thing to do'.

\footnotetext{
${ }^{2}$ Home income plans of this kind no longer exist in today's equity release market.
} 
In some cases, those who considered self-provision 'fair' explained their view with reference to inter-generational fairness; recognising the impact of requiring the income-tax paying population to bear the costs of the older generation's later life care. Mike, one of the youngest participants in our sample (aged 67), summarised his attitude to paying for care by saying: 'that is what the value in this house is for'. He added: 'I feel that all the fuss about selling the house to pay for care is because there are a load of middle class children who want to inherit their parents' money...' Trading off the desire to pass on wealth against the tax liabilities of the younger generation, Mike reasoned that:

it would be nice to let the children inherit something or to feel more secure even before we die. But in terms of care, to me the moral question is why should the wider community pay for my care so that my daughter can inherit the value of my house? What that actually means is that all the other people of her age are having to pay more taxes in order to pay for my care because I won't spend the value of my house (married, children, higher financial well-being, used ER to build extension, released $£ 55,000$ from house valued at $£ 300,000)$.

This was echoed by Henry, who said:

I think it's very wrong that public money should be spent in order to preserve the equity in a house for the children. I really think it's wrong...I don't know by what right people think it's appropriate that they should have their property preserved for the benefit of their children at cost to the state...

This preference for self-provision - at the cost of individual inheritance but to the benefit of the working-age generation more generally - was consistent with the overwhelming view amongst all our participants that they had been 'the lucky generation' (Bob, age 76); 'the golden generation' (David, age 76); 'much luckier than the present generation' (Dorothy, age 80).

I had security in my job, and my wife does. No fear of unemployment ever, and I switched jobs and in and out of the public sector. We've had the benefit of the most incredible health service imaginable. We were able to buy a property which although, as I say, we didn't look on it as an investment, it has been an incredible investment. (Bob, married, children, used ER to pay off mortgage and provide a safety net, released $£ 75,000$ from house valued at $£ 325,000$ )

I'd hate to be young now because for one thing there's no jobs about are there and you can't, to buy your own home now is almost impossible unless you've got a tremendous amount of money behind you... and most people haven't. (Dorothy, married, children, used ER to clear problem debt and have downstairs bathroom installed, released $£ 25,000$ from house valued at $£ 130,000$ ).

Reflecting perhaps the success of the Government's inter-generational narrative around care costs, the vast majority of our participants recognised the privileged position of their own generation. Yet, this overwhelming pro-social attitude towards inter-generational fairness was trumped in a slight majority of cases (discussed in the previous sections) by a proindividual attitude towards intra-generational fairness that in turn was rooted in assumptions of equal opportunity within generations under the 'ownership society'. 


\section{Conclusions}

For over a decade, debates about long-term care have revolved around the elusive quest for a system that is perceived to be fair. One of the crucial factors in achieving a 'fair system' is understanding what fairness means to those owners who, through their actions and behaviours, are key to effective implementation; yet this aspect of the care debate has been relatively underexplored. Our findings indicate that perceptions of 'fairness' in care funding debates operate on two intersecting planes: across and within generations. While the dominant narrative of inter-generational justice is well-placed to support self-provision, in preference to reliance on the working-age population, our findings indicate that perceptions of intra-generational unfairness - typically based on the assumption of a level-playing field to accumulate housing equity, and the assumption that those who have been successful have done so through hard work rather than through lucky circumstances - present a significant barrier to the idea that self-provision is 'fair'.

For those who thought self-provision unfair, this was generally linked to perceptions of within-cohort fairness between those who have accumulated (housing) assets and those who have not. These participants often explained their attitudes to paying for care with reference to their own experiences of having 'done the right thing' by paying taxes or mortgages, contrasting this with those who had not - who were viewed as irresponsible and undeserving of state support.. An important aspect of our findings was the feeling that policy expectations that those with assets should self-provide were a betrayal of the political rhetoric that had encouraged them to behave responsibly throughout their working lives, saving and investing in housing, such that they resented being asked to (continue to) pay for themselves in later life. In contrast to within-generation disadvantages, the relative disadvantage faced by younger generations was much more clearly recognised, particularly in terms of employment and access to home ownership. Crucially, however, attitudes to intra-generational fairness prevailed, ultimately determining whether participants considered self-provision 'fair'.

These findings run counter to previous research on attitudes to paying for care, where the sanctity of home or strong property rights, and/or inheritance motives played a more central role in peoples' sense of unfairness. The relative lack of such sentiments and attitudes in our study may be explained by the nature of the sample, so it would be worth exploring whether the questions we raise around the centrality of intra-generational fairness, could also help to better understand attitudes to paying for care among the general population of older owners.

Indeed, if further research were to indicate that these findings have a wider resonance beyond the equity release population, there are potentially significant implications for policies that seek to promote (property-) asset accumulation and welfare-supporting decumulation. For one thing, the source of unfairness in paying for care may have been misunderstood by policy makers which, as has been noted, emphasises the sanctity of the family home, The belief that some people, and not others, reach later life with higher levels of income and assets because they are the ones who have 'worked hard and done the right thing' - while those with lower, or no, housing wealth are undeserving squanderers, appears rooted in the official discourse of the 'ownership society' (Fox O'Mahony \& Overton, 2014b), and is compounded by the self-defeating consequences of anti-poverty policies that frame welfare provision as a burden upon those who pay income tax (Gubrium et al, 2013; Hills, 2014). The reinforcement of this narrative through political rhetoric may operate as a barrier to intragenerational solidarity thinking. Future research might also usefully pay attention to the likelihood that this may lead to adverse behaviours such as 'asset-dumping' strategies to avoid care cost liability, as well as dis-incentivising future cohorts of older owners from 
adopting the planned accumulation and decumulation strategies which asset-based welfare seeks to encourage.

\section{References}

Association of British Insurers (2014) Developing Products for Social Care, available online, https://www.abi.org.uk/ /media/Files/Documents/Publications/Public/2014/Social\%20care/D eveloping\%20Products\%20for\%20Social\%20Care\%20Report.ashx

Age UK (2014) Care in Crisis - What's next for social care? London: Age UK.

Boreham, R. and Lloyd, J.(2007) Asset Accumulation across the Life Course, London: ILC.

Burrows, R.(2003)'How the other half lives: An exploratory analysis of the relationship between poverty and home-ownership in Britain' Urban Studies,40:7,1223-42.

CFPB(Consumer Financial Protection Bureau)(2012)Reverse Mortgages - Report to Congress. Available at http://www.consumerfinance.gov/reports/reverse-mortgages-report/ (accessed 29 December 2015)

Commission on Funding of Care and Support(2011), Fairer Care Funding, Volume I, The Report of the Commission on Funding of Care and Support, Commission on Funding of Care and Support, London: The Stationary Office.

Croucher, K.and Rhodes,P.(2006) Testing Consumer Views on Paying for Long-Term Care, York: Joseph Rowntree Foundation.

Daily Mail (2014)'Revealed: How 10,000 families are paying massive care home bills they don't need to ... and how to make sure it doesn't happen to you' (13 June 2014), online at http://www.dailymail.co.uk/news/article-2657540/Revealed-How-10-000-families-payingmassive-care-home-bills-dont-need-make-sure-doesnt-happen-you.html

Deeming, C. and Keen, J. (2003)A fair deal for care in older age? Public attitudes towards the funding of long-term care, Policy and Politics, 31(4),pp.431-446

Department of Health (2013) 'Landmark reform to help elderly with care costs' press release, February 2013, available at https://www.gov.uk/government/news/landmark-reform-to-helpelderly-with-care-costs

Department of Work and Pensions (DWP) (2009), Spending priorities in the benefits system: Deliberative research with the public, Research Report No 559, London: DWP.

Doling, J. and Ronald, R. (2010) 'Home ownership and asset-based welfare', Journal of Housing and the Built Environment, 25: 2,165-173.

Dorling, D, Rigby, J., Wheeler, B., Ballas, D., Thomas, B., Eldin, F., Bordon, D. and Lupton, R. (2007), Poverty, wealth and place in Britain, 1968-2005, York: Joseph Rowntree Foundation.

Erens, B. and Turner, R.(1997) National survey on care for elderly people, London: Social and Community Planning Research.

Finch, J. and Mason, J.(2000) Passing on: Kinship and inheritance in England, London: Routledge.

Fox O’Mahony, L. and Overton, L.(2014a) Financial advice, differentiated consumers and the regulation of equity release transactions, Journal of Law and Society, 41(3), pp. 446-469

Fox O'Mahony, L. and Overton, L. (2014b) 'Asset-based welfare, equity release and the meaning of the owned home', Housing Studies, 29: 446-469.

Glendinning, C., Davies, B., Pickard, L. and Comas-Herrera, A. (2004),Funding Long-Term Care for Older People: Lessons from Other Countries, York: Joseph Rowntree Foundation.

Gubrium, E.K, Pellissery, S.\& Lødemel, I. (2013) The Shame of It: Global Perspectives on antipoverty policies, Bristol: Policy Press.

Gurney, C. (1999) 'Lowering the Drawbridge: A Case Study of Analogy and Metaphor in the Social Construction of Home-Ownership' Urban Studies, 36:10, 1705-22.

Hamnett, C., Harmer,M. and Williams, P. (1991), As Safe as Houses: Housing Inheritance in Britain, London: Paul Chapman. 
Hewitson,B., Seale, B. and Joyce, L. (2011) Commission on Funding of Care and Support, Public engagement exploring care and support funding options, TNS-BMRB Report of findings 224301.

Hills, J. (2014)Good times, bad times: the welfare myth of them and us, Bristol: Policy Press.

Hirsch, D. and Spiers, P. (2010) Funding Care: how can each generation pay its fair share? York: Joseph Rowntree Foundation.

HM Government (2008) The case for change: why England needs a new care and support systemengagement findings, London: DH

HM Government (2009) Shaping the Future of Care Together, Cm 7673, London: The Stationary Office.

House of Lords Select Committee on Public Service and Demographic Change (2013) Ready for Ageing? London: The Stationary Office.

Ipsos Mori (2011) Public opinion research on social care funding - A literature review on behalf of the Commission on the Funding of Care and Support, London: Ipsos Mori.

Jarvis,C., Stuchbury, R. and Hancock, R.(1998), 'Present indicative: findings from the ONS omnibus survey for the millennium debate of the age', Age Concern: London.

Keen, J. and Bell, D. (2009) Identifying a fairer system for funding adult social care, York: Joseph Rowntree Foundation.

KRS (2014) UK Equity Release Market Monitor - Half Year 2014, available at http://www.keyrs.co.uk/media/Key-Equity-Release-Market-Monitor-H1-2014.pdf

Kraus, M., Czypionka, T., Riedel, M., Mot, E. and Willemé, P.(2011) How European

Nations Care for Their Elderly. A New Typology of Long-term Care Systems. Assessing

Needs of Care in European Nations (ANCIEN) Policy Brief. Available online at

http://www.ancien-longtermcare.eu/policy_briefs

Leonard, P. (1997) Postmodern Welfare: Reconstructing an Emancipatory Project, London: Sage.

McKee, K. (2012) 'Young People, Homeownership and Future Welfare' Housing Studies, 27: 6, 853-862.

Mossialos, E., Dixon, A., Figueras, J., \& Kutzin, J.(eds.) (2002) Funding health care: options for Europe, Buckingham: Oxford University Press.

Maxwell, D. \& Sodha, S. (2006) Housing Wealth: First timers to old timers, London: IPPR

Mayhew, L., Karlsson, M. and Rickayzen, B. (2010)'The Role of Private Finance in Paying for Long-term Care' The Economic Journal, 120: 548,478-504.

Mayhew, L. and O'Leary, D.(2014) Unlocking the potential, London: DEMOS

Nyce, S.A, and Schieber, S.J. (2005)The Economic Implications of Aging Societies: The Costs of Living Happily Ever After, Cambridge: Cambridge University Press

ODPM and HM Treasury (2005), Extending Home Ownership, London: ODPM.

Ong, R., Jefferson, T., Wood, G., Haffner, M. \& Austen, S.(2013) Housing Equity Withdrawal: Uses, Risks, and Barriers to Alternative Mechanisms in Later Life, AHURI Final Report No.

217 (Melbourne: Australian Housing and Urban Research Institute)

ONS (2015) Wealth in Great Britain Wave 4, 2012-214, Chapter 3: Property Wealth, Wealth in Great Britain, 2012-2014, available online at http://www.ons.gov.uk/ons/rel/was/wealth-ingreat-britain-wave-4/2012-2014/index.html

Opinion Leader (2009) It's a heck of a gamble, isn't it? Attitudes of older people towards the use of assets for pooling risk of care costs, A report by Opinion Leader for Age Concern England, London: Age Concern

Overton, L. (2010) Housing and Finance in Later life: A study of UK equity release customers, London: Age UK.

Overton, L. and Fox O’Mahony, L.(2015) Consumer Demand for Retirement Borrowing, London: Council for Mortgage Lenders

Parker, G. and Clarke, H.(1997) 'Will you still need me? Will you still feed me? Paying for 
care in old age', Social Policy and Administration, 31:2,119-35

Pickard, L. (2013) 'A growing care gap? The supply of unpaid care for older people by their adult children in England to 2032', Ageing and Society, 35: 1, 96-123

Prabhakar, R. (2008)The Assets Agenda, London: Palgrave Macmillan

Price, D., Bisdee, D., Daly, T., Livsey, L. and Higgs, P. (2014) 'Financial planning for social care in later life: the 'shadow' of fourth age dependency, Ageing and Society, 34, pp 388-410

Rose, N.(1996) 'Governing "advanced” liberal democracies' in A. Barry, T. Osborne and N. Rose (eds.), Foucault and Political Reason, London, UCL Press, pp.144-164

Rowlingson, K. and McKay, S.(2005) Attitudes to Inheritance in Britain, York: JRF.

Rowlingson, K. (2006) 'Living poor to die rich'? or 'spending the kids' inheritance? Attitudes to assets and inheritance in later life, Journal of Social Policy, 35(2), pp. 175-192.

Searle,B. andMcCollum,D. (2014) 'Property-based welfare and the search for generational equality', International Journal of Housing Policy, 14:4,325-43

Smith, S.J. (2008) 'Owner-occupation: at home with a hybrid of money and materials', Environment and Planning A,40,520-35.

Smith, S.J. and Searle, B.A. (2008)'Dematerialising money: the ebb and flow of wealth between housing and other things', Housing Studies,23:1,21-43.

Spencer, L., Ritchie, J. and O'Connor, W. (2003), 'Carrying out Qualitative Analysis' in J. Ritchie and J. Lewis (eds.) Qualitative Research Practice, London: Sage, pp. 219-262

Taylor-Gooby, P.(2008) 'Choice and Values: individualized rational action and social goals', Journal of Social Policy, 37:2,167-1.

Toussaint, J. and Elsinga, M.(2009) Exploring 'housing asset-based welfare': Can the UK be held up as an example for Europe? Housing Studies, 24(5), pp. 669-692

The World Bank (2004)Averting the Old Age Crisis: Policies to Protect the Old and Promote Growth, New York: Oxford University Press

Wanless, D., Forder, J., Fernàndez, J.L., Poole, T., Beesley, L., Henwood, M. and Moscone, F.(2006) The Wanless social care review: securing good care for older people-taking a long-term view, London: King's Fund

Willetts, D.(2010) The Pinch, London: Atlantic books. 